\title{
Effects of Districting Systems on Republican Representation in Southern State Legislatures
}

\author{
Malcolm E. Jewell, University of Kentucky \\ David A. Breaux, Mississippi State University
}

An analysis of voting patterns in the lower houses of legislatures in nine southern and border states from 1968 to 1986 shows that the Republican party has benefitted from the use of singlemember districting. The Republican ratio of seats to votes has been consistently higher in singlemember than in multimember districts, though the magnitude of that difference varies considerably from state to state. The Republican seats/votes ratio in particular types of districts varies from state to state, however, depending on several other variables such as the size of the Republican vote and those factors that affect the slope of the regression between votes and seats.

Since the mid-1960s there has been an unsteady growth in the number of Republican seats in southern state legislatures; and in many of these there has been an increase in the proportion of districts that elect only a singlemember. The purpose of this paper is to test the hypothesis that the Republican party, because of its minority status, is better able to convert votes into legislative seats in single-member than in multimember districts. If that is true, we can conclude that the shift toward single-member districting helps to explain the growth in the Republican share of legislative seats.

Political scientists have assumed that, if group membership serves as a voting cue, the use of multimember districts disadvantages the minority group. Multimember districts afford the majority group a greater likelihood of sweeping all of the seats in an election than do single-member districts. Evidence concerning the under-representation of racial minorities in state legislative elections supports this assumption (Grofman 1981; Grofman and Handley 1991; Grofman, Migalski and Noviello 1986; Jewell 1980, 1982; Bullock and Gaddie 1993). However, evidence concerning the impact of multimember districts on partisan representation is mixed (Walker 1976; Rosenthal 1981; Niemi, Hill and Grofman 1985; Bullock and Gaddie 1993).

In this paper we focus on southern states because this is the region in which there have been the most drastic changes from large multimember to

MALCOLM E. JeWELl is Professor Emeritus at the University of Kentucky.

DAVID A. BREAUX is Associate Professor of Political Science at Mississippi State University.

The American Review of Politics, Vol. 16, Spring, 1995: 1-14

(1995 The American Review of Politics 
single-member districts and at the same time major increases in the proportion of seats held by Republicans.

\section{Data and Method}

The State Legislative Elections Project under the auspices of the Interuniversity Consortium for Political and Social Research (ICPSR) has collected and compiled computer files on legislative elections in the 50 states for the 1968 to 1986 time period, making possible detailed analysis of legislative elections. The analysis presented in this paper is based on general election data from nine southern and border states-Georgia, Kentucky, Maryland, Missouri, North Carolina, South Carolina, Tennessee, Texas, and Virginia for the 1968 to 1986 time period. (Alabama and Mississippi are omitted from the analysis because the proportion of seats contested by Republicans, and particularly the seats won, were substantially lower than in the other southern states. Louisiana is omitted because its unique nonpartisan election system makes comparison with other states difficult. Arkansas and Florida are omitted because of data limitations.)

The data analyzed in this paper come from the State Legislative Elections Project of the ICPSR and more specifically from the candidateconstituency file. This file provides information on each candidate, including party membership and the votes cast for the candidate, plus information on the type of electoral district. Because there are typically a greater number of house districts than there are senate districts in a state, and because most state senates follow a staggered election schedule, the analysis will focus solely on partisan competition in southern state house elections.

Kentucky and Missouri used single-member districts exclusively throughout the period, and Tennessee almost exclusively. Georgia, Maryland, and North Carolina used a combination of multimember and singlemember districts throughout the period. South Carolina, Texas, and Virginia used a combination of the two types at the start of the twenty-year period, and shifted to exclusive use of single-member districts at various times during the period. ${ }^{1}$

Thus we are able to compare the relationships between Republican votes and seats in states using different types of districting, and in states shifting from a mix of districts to exclusive reliance on single-member districts.

It is important to make clear from the start the limitations of this analysis. There are differences among the states in the patterns of distribution of Democratic and Republican voters. Therefore, if Republicans appear to do better in a state using single-member districts exclusively than in one 
using a mixture, this does not prove that the districting system is the cause of this advantage. The same point can be made about differences within states. For example, if the Republicans have more voting strength in metropolitan areas of a state, and if these areas make greater use of multimember districts, we should be cautious about jumping to the conclusion that multimember districting benefits the Republican party.

The states that have shifted from a mixture of districts to exclusive reliance on single-member districts offer a better opportunity for comparison. If the Republican party were to gain seats after such a change, there would be more reason to conclude that a change in districting had made the difference. But it is difficult to control for other variables, such as gains or losses in Republican voting strength. Moreover, the scope of this analysis is statewide and not local. If a particular metropolitan county shifts from multimember to single-member districting, we have not analyzed the resulting changes in that county.

In theory, multimember districting hurts a minority party because, in a given county or cluster of counties, pockets of minority party strength are overwhelmed by the majority party; the minority party, which might win some proportion of single-member districts, may win no seats in a large multimember district. Whether the districting pattern actually has this effect depends on a number of variables, including the extent of straight-party voting, the size and geographical concentration of the minority party voting strength, and the extent of partisan gerrymandering.

The states in this study employed two kinds of multimember districts. Maryland, North Carolina, South Carolina, and Virginia use (or used) what we call "free-for-all" multimember districts. Every candidate (of both or all parties) runs against all of the other candidates. In Georgia and Texas multimember districts are divided into positions (or posts), designated 1, 2, 3, or A, B, C. Candidates must file for a specific position and run against only the others in that position. (Several of the North Carolina multimember districts also used positions in the 1970 election.)

A party's tactics in running candidates might be affected by the type of multimember district. In a free-for-all district a minority party might run fewer candidates to encourage "single-shot" voting and try to elect at least one. In a district with positions, there is no tactical advantage to running fewer candidates.

It is common knowledge that, in legislatures with single-member districts, the majority party normally wins a proportion of seats greater than its proportion of votes, and this advantage should be larger as the size of the majority increases. The minority party wins seats only because it has majority strength in some districts. In theory, the majority party should have an 
even greater ratio of seats to votes in multimember districts because pockets of minority party strength are swallowed up by the majority. (This would obviously be less true if the minority party held a majority in some multimember districts.) Thus, if we can calculate the ratio of seats to votes for each party in both types of districts, we should be able to determine whether this ratio varies by district type, though we may be cautious is asserting that the differences are caused by the different types of districts used.

It is difficult, however, to determine what rules to follow in calculating the votes cast for the candidates of a party in free-for-all multimember districts, particularly when one or both of the parties runs fewer candidates than the number of seats in the district. In such instances, voters are permitted to vote for as many candidates as there are seats to be filled, though they may not choose to cast that many. Therefore, we must use some method for averaging these votes rather than adding them together, in order to estimate the vote cast for each party. In calculating a party's votes we must not double-count or triple-count those voters who can vote two or three times.

We have used two different methods for calculating these averages in free-for-all multimember districts. First, we have divided the number of votes for a party's candidates by the number of its candidates running in the district. The purpose is to provide a more accurate measure of the party's voting strength in each district, and ultimately in the state. This assumes that voting strength is a meaningful concept and that, faced with less than a full slate of candidates, many partisans will reduce the number of votes they cast rather than cross party lines.

Secondly, we have divided each party's vote by the number of seats in the multimember district. This describes reality better if party allegiance is weak and most voters choose to use all of their votes. It can also be argued that this method of calculation is a more accurate measure of the votes actually cast, as distinct from partisan voting strength. We will employ both methods in the analysis of free-for-all multimember districts.

For each state and each election year from 1968 through 1986 we have calculated the proportion of seats won by each party and the proportion of votes cast for the legislative candidates of each party, and these data are also broken down by the type of district. (There are ten elections for most states, eleven in Virginia, nine in Kentucky, five in Maryland, and data are available for only eight elections in North Carolina.) (We have omitted a very small number of multimember districts in Tennessee in 1968 and 1970 because the numbers are too small for useful analysis.) 


\section{Translating Votes Into Seats}

Table 1 shows the ratio between the proportions of Republican seats and of Republican votes by state, type of district, and time period. The time periods are divided into two equal parts except in states where there was a major shift in the proportion of single-member seats; the time periods are before and after that shift.

\section{Effects of Districting}

For the states as a whole, the ratio of the proportion of Republican seats to votes is considerably higher in single-member than in free-for-all multimember districts (measured either way), and it is lowest in the multimember districts that use positions (Table 1). But, because Republican strength varies considerably from state to state and from time to time, it is more meaningful to examine differences in the individual states for comparable periods.

In both Georgia and Texas, the Republican ratio was considerably higher in single-member than in than in multimember position districts. In both states Republican candidates won both a larger share of the vote and fewer seats in multimember than in single-member districts. In North Carolina the Republican ratio was much lower in multimember position districts, but these were used only one year.

The contrasts between types of districts are less well defined in the states that have used both single-member and free-for-all multimember districts. This is partly because we have used two methods to define the Republican proportion of votes in these multimember districts. The use of the total number of seats in a district, instead of the number of Republican candidates, as the divisor reduces the party's proportion of votes and thus increases the Republican ratio of seats to votes.

In Maryland the Republican ratio is much higher in single-member districts, but there are so few of these ( $10 \%$ or fewer of such seats) that the differences are less important. Moreover, the proportion of the Republican vote was higher in single-member districts, which helps to explain the higher ratios. In North Carolina the Republican ratio is higher in singlemember districts than in free-for-all multimember districts, but the differences are modest, and are even smaller when the district seats are used to calculate the Republican share of the vote. Moreover, the proportion of members elected in single-member districts was eight percent or less until the 1982 election. 
Table 1. Ratio of Republican Seats to Votes, by State, Type of District, and Time Period

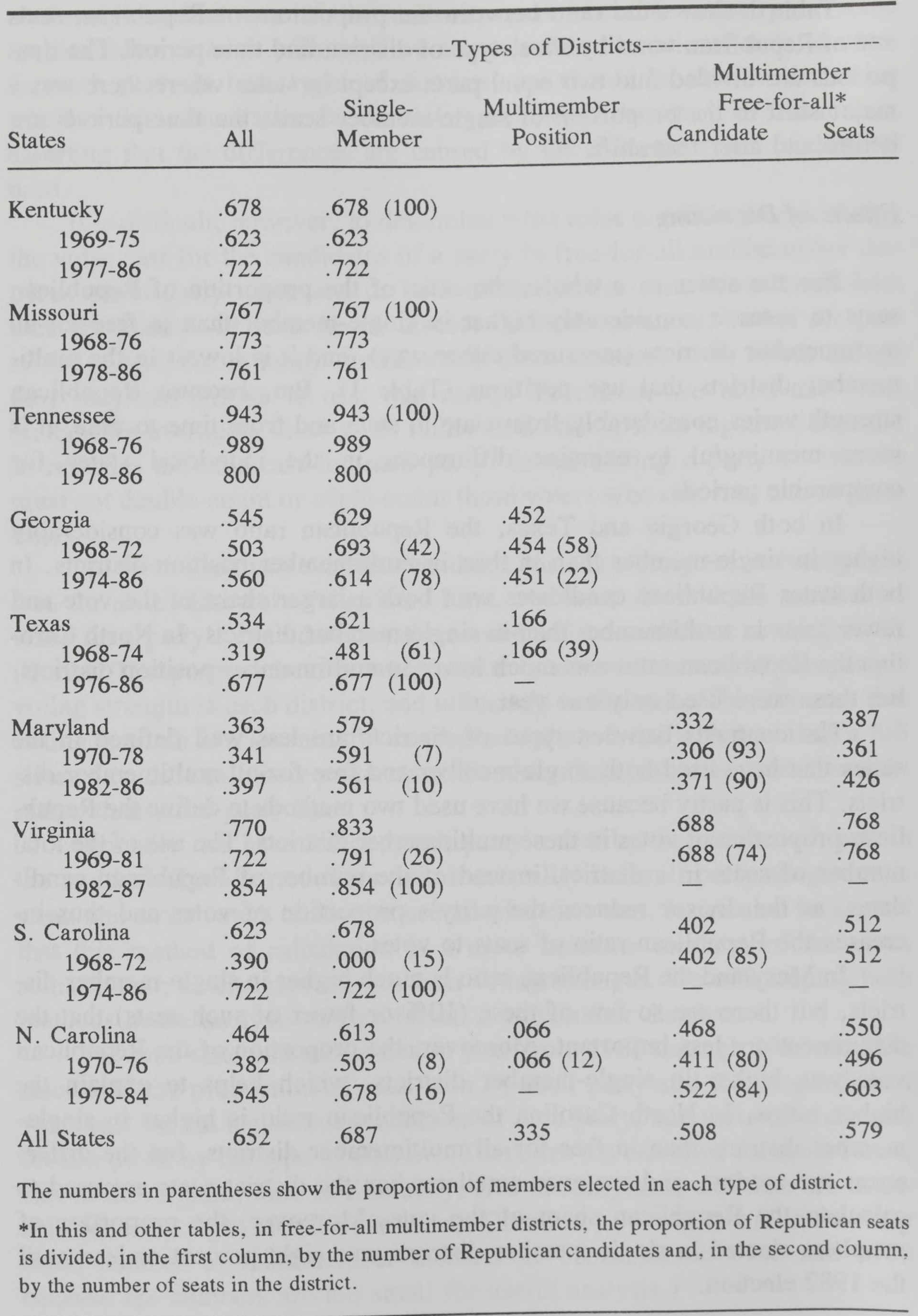


During the three elections in which South Carolina used multimember districts (for most seats) the proportion of the vote in these districts (however measured) was greater than in single-member districts; the party won a modest number of multimember seats, compared to none in singlemember districts. When the state shifted entirely to single-member districts in 1974, however, the Republican ratio became much higher than it had been in the multimember districts in the earlier period. In the 1974-86 elections Republican candidates never gained as large a proportion of the vote as they had done in multimember districts in 1970 and 1972 (measured by either method); but their share of seats in the later period was higher than in those early elections. This comparison over time suggests that in South Carolina the shift to single-member districts helped the Republican party.

In Virginia, during the period when both kinds of districts were used, the Republican ratio was higher in single-member districts, but the difference becomes very small when Republican votes are calculated on the basis of district seats. During most of the 1969-81 period, a fourth or fewer of the seats were in single-member districts. During that period, Republicans won a larger proportion of the vote (by either calculation) in multimember districts, but Republican candidates in single-member districts increased their share of both votes and seats in the 1977-81 elections. In the 1982-87 elections, with only single-member districts in use, the Republican ratio was higher than it had been in either type of district previously.

Because minor party legislative candidates were particularly strong in the 1969-75 Virginia elections, Republican and Democratic votes are calculated as a percentage of the vote for all parties (not just the vote for major parties as in the other states). Although the minor party candidates won a few seats, most votes were wasted; this results in an increase in the seats/votes ratio of both major parties.

\section{Effects of Variations in Contested Elections}

The seats/votes ratio in all states is also affected by the proportion of seats that the Republican party contests. There is a positive correlation between the proportion of seats the Republicans contest and the proportion they win, but it is a relatively modest .566 .

If only contested races are measured, the Republican party's share of both seats and votes increases; some increase in its seats/votes ratio might be expected. We have looked at the Republican seats/votes ratio in those single-member districts that were contested by both parties. (This excludes a substantial number of seats uncontested by Democrats, particularly in 
Kentucky, Tennessee, and Missouri, and in other states in the most recent years). We examine only single-member districts because many multimember districts are partially contested. (Virginia is excluded because of the large number of third-party candidates.)

The Republican ratio of seats to votes in single-member districts averages .06 higher in contested races, but there is some variation among the states. The ratio is actually very slightly lower in contested districts in two states, Maryland and Missouri, that have the highest proportion of seats contested by Republicans (though Maryland has a very small number of single-member districts). In Tennessee, the very high Republican ratio of .943 increases to 1.034 in contested races, where the party actually won a majority of seats. The largest difference is in Georgia, where the Republicans contested the fewest seats; the ratio increases from .629 to .788 in contested seats.

If the Republican party contests a large number of seats where it gets relatively few votes and has no chance of winning, it is wasting votes and its ratio of seats to votes should be lower. Alternatively, if the Republican party targets districts more carefully and discourages candidates from running in hopeless seats, it should get fewer total votes but a higher ratio of seats to votes. In recent years, in states such as Texas and South Carolina, the Republican party has been improving its seats/votes ratio in singlemember districts, winning seats faster that it has increased the number of candidates, which suggests a policy of more careful targeting.

\section{Table 2. Comparison of Republican Seats/Votes Ratios in All Single-Member Districts and in Those Contested by Both Parties}

\begin{tabular}{lcccc}
\hline & \multicolumn{3}{c}{ Single-Member Districts } & $\begin{array}{c}\text { Percentage of } \\
\text { Seats Contested }\end{array}$ \\
States & All & Contested & Difference & By Republicans \\
\hline Kentucky & .678 & .695 & .017 & 57.7 \\
Missouri & .767 & .759 & -.008 & 71.8 \\
Tennessee & .943 & 1.034 & .091 & 63.6 \\
Georgia & .629 & .788 & .159 & 27.8 \\
& .621 & .713 & .092 & 45.5 \\
Texas & .579 & .567 & -.012 & 80.7 \\
Maryland & .678 & .750 & .072 & 36.6 \\
S. Carolina & .613 & .687 & .074 & 69.0 \\
N. Carolina & & & & \\
\end{tabular}




\section{Other Causes of Interstate Variation}

We would expect to find variations among the states in the ratio of Republican seats to votes that can not be explained by differences in districting. In seeking explanations of interstate variations within each type of district, we will examine the results of regression analyses (Table 3) and estimate how many seats Republican legislators would win if the party got $50 \%$ of the vote (Table 4 ).

The larger the proportion of the total statewide legislative vote won by a party, the larger its ratio of seats to votes should be. A party that gets two-thirds of the votes in a state, for example, would be expected to win a substantially larger proportion of seats. On the other hand, a party winning

\section{Table 3. Regression of Republican Percentage of Seats on Percentage of Votes: Intercept and Slope}

\begin{tabular}{|c|c|c|c|c|c|}
\hline \multirow[b]{2}{*}{ States } & \multirow[b]{2}{*}{ All } & \multirow{2}{*}{$\begin{array}{l}\text { Single- } \\
\text { Member }\end{array}$} & \multirow{2}{*}{$\begin{array}{l}\text { Multimember } \\
\text { Position }\end{array}$} & \multicolumn{2}{|c|}{$\begin{array}{l}\text { Multimember } \\
\text { Free-for-all* }\end{array}$} \\
\hline & & & & Candidate & Seats \\
\hline \multirow[t]{2}{*}{ Kentucky } & Intercept & 13.045 & & & \\
\hline & Slope & .313 & & & \\
\hline \multirow[t]{2}{*}{ Missouri } & Intercept & 5.092 & & & \\
\hline & Slope & .646 & & & \\
\hline \multirow[t]{2}{*}{ Tennessee } & Intercept & -19.768 & & & \\
\hline & Slope & 1.407 & & & \\
\hline \multirow[t]{2}{*}{ Georgia } & Intercept & .435 & 5.337 & & \\
\hline & Slope & .615 & .242 & & \\
\hline \multirow[t]{2}{*}{ Texas } & Intercept & -10.635 & -32.428 & & \\
\hline & Slope & 1.023 & 1.112 & & \\
\hline \multirow[t]{2}{*}{ Maryland } & Intercept & -2.498 & 6.111 & 2.702 & \\
\hline & Slope & .642 & .153 & .294 & \\
\hline \multirow[t]{2}{*}{ Virginia } & Intercept & -4.105 & 33.564 & 25.184 & \\
\hline & Slope & .967 & -.231 & -.005 & \\
\hline \multirow[t]{2}{*}{ S. Carolina } & Intercept & -3.937 & -3.922 & .943 & \\
\hline & Slope & .913 & .563 & .441 & \\
\hline \multirow[t]{2}{*}{ N. Carolina } & Intercept & -21.642 & -51.006 & -23.619 & \\
\hline & Slope & 1.177 & 1.919 & 1.322 & \\
\hline \multirow[t]{2}{*}{ All States } & Intercept & -5.899 & 7.823 & -9.756 & -7.421 \\
\hline & Slope & .913 & .046 & .815 & .827 \\
\hline
\end{tabular}




\section{Table 4. Percentage of Seats Republican Party Would Gain If it Won 50 Percent of Seats, by State and Type of District}

\begin{tabular}{|c|c|c|c|c|c|}
\hline \multirow[b]{2}{*}{ States } & \multirow[b]{2}{*}{ All } & \multirow{2}{*}{$\begin{array}{l}\text { Single- } \\
\text { Member }\end{array}$} & \multirow{2}{*}{$\begin{array}{l}\text { Multimember } \\
\text { Position }\end{array}$} & \multicolumn{2}{|c|}{$\begin{array}{l}\text { Multimember } \\
\text { Free-for-all* }\end{array}$} \\
\hline & & & & Candidate & Seats \\
\hline Kentucky & & 29 & & & \\
\hline Missouri & & 42 & & & \\
\hline Tennessee & & 51 & & & \\
\hline Georgia & & 31 & 17 & & \\
\hline Texas & & 41 & 23 & & \\
\hline Maryland & & 30 & 14 & 17 & \\
\hline Virginia & & 44 & 22 & 25 & \\
\hline S. Carolina & & 42 & 24 & 31 & \\
\hline N. Carolina & & 37 & 45 & 42 & \\
\hline All States & & 40 & 10 & 31 & 34 \\
\hline
\end{tabular}

less than a third of the vote might win a much smaller share of seats because most of its votes are wasted in districts where it loses.

If a political party's share of seats increases faster than its share of votes, this phenomenon might take either of two forms. If the relationship is linear, the gain would be at a steady rate; if it is curvilinear, the rate would increase as the share of votes grows. For example, in a linear relationship, if the intercept were -15 and the slope were 1.3 , the party would get $24 \%$ of the seats for $30 \%$ of the vote, $50 \%$ for $50 \%$, and $76 \%$ of the seats for $70 \%$ of the vote. If the relationship were curvilinear, the party might get only $18 \%$ of the seats with a $30 \%$ vote, $50 \%$ for $50 \%$, and $95 \%$ with $70 \%$ of the seats, for example.

The Republican party did not win a majority of votes or of seats in any of the states for any of the elections covered in this study. Therefore, we would not expect the Republican seats/votes ratio to approach 1.0 in any state. But we might expect to find that the ratio was higher, controlling for type of district, in those states where the average Republican percentage of the vote was higher.

The four states with the highest Republican ratios of seats to votes (for all districts and for single-member ones) are (in order) Tennessee, Virginia, Missouri, and Kentucky. If we exclude two states, Maryland and North Carolina, with very few single-member districts, the three states with the highest average proportion of Republican votes in single-member districts 
highest average proportion of Republican votes in single-member districts are Tennessee, Missouri, and Kentucky, in that order. (The high ratio in Virginia results in part from the substantial number of votes cast for third party candidates.) South Carolina, with the smallest average proportion of Republican votes has the lowest Republican ratio.

A scattergram of single-member districts in all states shows that the relationship is roughly a linear one (with an intercept of -5.899 , a slope of .913 , and a correlation of .890) (Table 3). At the top of the slope are several Tennessee elections, including three in which the share of seats equalled or slightly exceeded the share of votes. The slope for Tennessee single-member districts is 1.407 , and the regression indicates that the Republicans could win $51 \%$ of the seats with $50 \%$ of the vote-the highest proportion for any of the district systems in any state. There is an additional explanation for the unusually high Republican ratio in Tennessee. The Republicans won slightly more than half of the contested races in Tennessee, but less than one-third of the uncontested races. Over $60 \%$ of Democratic victories came in uncontested seats, where the Republican party was not wasting votes, and thus the Democrats did not enjoy as large a seats/votes ratio as the majority party would normally gain.

Also high on the slope are several Missouri elections; but the slope is only .646 , and $50 \%$ of the vote would win only $42 \%$ of seats. In several Virginia elections the Republican share of single-member seats came close to the share of votes, even though the latter was one-third or less, partly because of the large number of wasted third-candidate votes; the slope was .967 , and Republicans could win $44 \%$ of seats by winning half the votes. Although Kentucky Republicans averaged $36 \%$ of the vote (and ranged from 32 to $45 \%$ ), there was little relationship between the share of seats and of votes; the slope was only .312, the correlation only .536; and half the votes would produce only $29 \%$ of seats.

Near the bottom of the slope are some of the early single-member district elections in South Carolina and Texas and most of the Georgia elections, in which the Republican proportion of the vote was quite low. When the Republican vote began to grow in South Carolina and Texas, there were substantial increases in seats, as the size of the slopes indicate, and each party could win over $40 \%$ of the seats with half the vote. By contrast, growth in seats was limited in Georgia.

When we examine the scattergrams for free-for-all multimember districts, as a whole (using both methods of measurement), we find that the slopes are smaller than in single-member districts, indicating that increases in votes produced smaller gains in seats. The correlations are also smaller (.610 and .669 by the two measurements, compared to .890 for single- 
member districts). The pattern of seats and votes is quite different for the various states. In North Carolina both the slope and correlation are high. It is the only state in which the Republicans would win over $40 \%$ of the multimember seats if it could get $50 \%$ of the vote. In South Carolina (which had only three elections with multimember seats), the slope is much more modest though the correlation is high. In Virginia the slope is slightly negative but the correlations are so low as to make the relationship almost meaningless (in sharp contrast to the high correlation in the state's singlemember districts). Finally, in Maryland the slope is positive but nearly flat and the correlations are weak; this is compatible with a very low ratio of Republican seats to votes, and a very low projected share of seats if the party got half the vote.

The Republican seats/votes ratio is lowest in multimember districts with positions (.335), but the small number of elections (mostly in Georgia) makes analysis more difficult. In Georgia the slope is very small, and thus a win of half the votes would only produce one-sixth of the seats for Republicans. The ratio of seats to votes had not improved in recent years. In the first two Texas elections the Republicans averaged eight percent of seats for $36 \%$ of the vote; in the next two they won no seats with an average of $29.5 \%$ of the vote. The result was a minuscule .166 ratio of seats to votes.

\section{Conclusions}

The Republican ratio of seats to votes in southern and border states has been consistently higher in single-member than in multimember districts. In those states that have used both single-member and multimember districts, the Republican ratio has been higher in single-member districts, and in those states that abandoned multimember districts during the period covered there has also been an increase in the Republican seats/votes ratio.

The differences in the Republican ratios between the two types of districts is particularly striking in Georgia and Texas, the two states using multimember districts with positions. In South Carolina the shift to the exclusive use of single-member districts seems clearly to have contributed to a large increase in the Republican seats/votes ratio. In Maryland, the importance of a relatively large contrast between types of districts is reduced because very few seats ( $10 \%$ or fewer) were in multimember districts. In the other two states, North Carolina and Virginia, the contrasts between the two districting systems are more modest.

In these two states where the contrasts are smallest, they almost vanish when the Republican proportion of the vote is calculated using the number of seats (not Republican candidates) in each district. The problem of making 
this calculation is not just a methodological one; it raises a question of just what we mean by a party's vote in a free-for-all multimember district. There is really no "right" or "wrong" answer, particularly in the absence of information about how many votes minority-party loyalists cast when their party runs less than a full slate of candidates.

Variations among the states in the Republican seats/votes ratio can be explained by several factors other than the type of districts used. States with a higher proportion of Republican votes, like Tennessee and Missouri, have higher Republican ratios, while the lower proportion of Republican votes in states like South Carolina and Georgia contributes to a lower ratio. There are interstate differences in the distribution of Democratic and Republican voters and the pattern of contested seats. These contribute to considerable differences in the size of the slope, when Republican votes are regressed against seats. And this obviously affects how large a share of seats the Republicans get when they begin to make electoral gains.

There is evidence that in recent years both political parties in southern and border states have become more selective in the seats they contest (Jewell and Breaux 1990). We need to learn more about how districting patterns affect these decisions on running candidates. We need more research on split-ticket voting in multimember districts, particularly in the South (see Niemi, Hill and Grofman 1985, and Niemi, Jackman, and Winsky 1991). Virtually nothing is known about voting patterns and the number of votes cast in multimember districts when one party runs an incomplete set of candidates (see Niemi, Jackman, and Winsky 1991).

\section{NOTES}

Data for this paper come from the State Legislative Elections Project and were made available by the Inter-University Consortium for Political and Social Research. The Consortium bears no responsibility for the analysis or interpretations presented here.

${ }^{1}$ Tennessee and Georgia made some use of floterial districts during this time period. A floterial district is one that encompasses or overlaps two or more smaller districts. The floterial district and the districts it overlaps may be either single- or multimember. Since there are so few of these districts, and since they overly complicate the task of calculating the number of votes cast in a district, they are excluded from our analysis.

\section{REFERENCES}

Bullock, Charles S. III, and Ronald Keith Gaddie. 1993. Changing from Multimember to Single-member Districts: Partisan, Racial, and Gender Consequences. State and Local Government Review 25:155-63. 
Grofman, Bernard. 1981. Alternatives to Single-member Plurality Districts: Legal and Empirical Issues. Policy Studies Journal 9:875-898.

Grofman, Bernard, and Lisa Handley. 1991. The Impact of the Voting Rights Act on Black Representation in Southern State Legislatures. Legislative Studies Quarterly 16:111-128

Grofman, Bernard, Michael Migalski, and Nicholas Noviello. 1986. Effects of Multimember Districts on Black Representation in State Legislatures. Review of Black Political Economy 14:65-78.

Jewell, Malcolm E. 1980. The Consequences of Legislative Districting in Four Southern States. Paper presented at the Citadel Symposium on Southern Politics, Charleston, $\mathrm{SC}$.

1982. The Consequences of Single- and Multimember Districting. In Bernard Grofman, Arend Lijphart, Robert McKay, and Howard Scarrow eds., Representation and Redistricting. Lexington, MA: Lexington Books.

Jewell, Malcolm E., and David A. Breaux. 1990. Patterns of Electoral Competition in Southern State Legislative Elections. Paper presented at the annual meeting of the Southern Political Science Association, Atlanta, GA.

Niemi, Richard G., Jeffrey S. Hill, and Bernard Grofman. 1985. The Impact of Multimember Districts on Party Representation in U.S. State Legislatures. Legislative Studies Quarterly 10:441-455.

Niemi, Richard G., Simon Jackman, and Laura R. Winsky. 1991. Candidacies and Competitiveness in Multimember Districts. Legislative Studies Quarterly 16:91-110.

Rosenthal, Alan. 1981. Legislative Life: People, Process, and Performance in the States. New York: Harper and Row.

Walker, Roland. 1976. One Man-One Vote: In Pursuit of an Elusive Ideal. Hastings Constitutional Law Quarterly 3:453-484. 